\title{
An Assessment of Customer's Preferences on The Selection of Takaful Over Conventional: A Case of Saudi Arabia
}

\author{
Faisal Nazir Hussain ${ }^{1}$, Azman Bin Mohd. Noor ${ }^{2}$
}

\begin{abstract}
This paper aims at assessing the motivational factors that influence the customer's preferences of takaful over conventional insurance. The customers' information about the takaful products and services based on sharia are identified in order to enable them differentiate takaful and conventional insurance. The research uses mixed method of data collection. This comprises of questionnaires and in-depth interviews with the respondents from four selected takaful industries in Saudi Arabia. The questionnaires were analysed using simple percentages and for the interviews, thematic analyses were used. Based on the findings of the study, the customer's preferences on the selection of takaful over conventional insurance include protection of takaful product by sharia, support from the government. Similarly, the absence of risk incurred or transferred to participants, funds contributed in the spirit of brotherhood for all members. Moreover, another customer's preferences is that contributions (tabarru') are invested in non-interest based capitalization by the takaful agents and profits are shared according to individual contributions. Based on takaful, donations are established at the pooling system in line with sharia and they are formed on the bases of sympathy, consciousness of the idea of tabarru' as well as abstaining from gharar, maysir and riba.
\end{abstract}

Keywords: takaful, insurance, customer preferences

Abstrak. Tulisan ini bertujuan untuk menilai faktor-faktor motivasi yang mempengaruhi preferensi pelanggan pada asuransi syariah dibandingkan dengan asuransi konvensional. Informasi pelanggan tentang produk-produk dan layanan-layanan Takaful berdasarkan syariah diidentifikasi untuk memungkinkan mereka membedakan asuransi Takaful dan konvensional. Penelitian ini menggunakan metode campuran dalam pengumpulan data. Ini terdiri dari kuesioner dan wawancara mendalam dengan responden dari empat industri takaful terpilih di Arab Saudi. Kuesioner dianalisis menggunakan persentase sederhana dan untuk wawancara, analisis tematik digunakan. Berdasarkan temuan penelitian, preferensi pelanggan pada pemilihan takaful atas asuransi konvensional termasuk perlindungan produk takaful oleh syariah, dukungan dari pemerintah. Demikian pula, tidak adanya risiko yang ditimbulkan atau dialihkan kepada peserta, dana disumbangkan dalam semangat persaudaraan untuk semua anggota. Selain itu, preferensi pelanggan lain adalah bahwa kontribusi (tabarru ') diinvestasikan dalam kapitalisasi berbasis non-bunga oleh agen-agen takaful dan keuntungan dibagi berdasarkan kontribusi individu. Berdasarkan takaful, donasi dibentuk pada sistem pengumpulan yang sejalan dengan syariah dan mereka dibentuk atas dasar simpati, kesadaran akan gagasan tabarru' dan terbebas dari gharar, maysir dan riba.

Kata kunci: takaful, ansuransi, preferensi nasabah.

\footnotetext{
${ }^{1}$ Institute of Islamic Banking and Finance, IIUM, Malaysia | faisalnazir732@gmail.com

${ }^{2}$ Institute of Islamic Banking and Finance, IIUM, Malaysia | azmann@iium.edu.my
} 


\section{Introduction}

Vulnerabilities and disasters are the natural phenomena that may happen to any individual. Some are anticipated, such as retirement, old age and death while others are unexpected such as road accidents, fire, outbreak, flood, hurricane, electrocution, thunder, epidemic, war, disease etc. These hazards can occur to someone's life, his properties or sometimes his business undertakings. The risks frequently affect the lives of many people in the society which at times becomes overwhelming and devastating. The consequences may result into susceptibility and helplessness of these unfortunate people. Similarly, the persistent needs of consumers in the modern world revolve around the need for security, i.e. security for life and properties (Abdul-Hamid et al., 2009).

Takaful has been well received globally as an alternative to conventional insurance. Takaful as a sharia compliance Islamic insurance product, holds an idea different from that of the conventional insurance that is totally prohibited by the sharia because of elements of interest (riba), uncertainty (gharar), and gambling (maysir). There is doubt of what the consumer is purchasing or paying for, if there is no loss the consumer obtains nothing. If loss takes place, the consumer gets compensation in varying amounts. Another element in conventional insurance is the issue of gambling (maysir) and the last one is the element of riba where insurance funds are usually invested in interest-bearing securities. Consequently, Takaful is a substitute for conventional insurance, which manifests itself in the form of shared assistance ( $\left.t a^{\prime} a w u n\right)$ in promoting moral virtue by supporting those in needs or in difficulties (Amin, 2012).

Takaful consumers donate money to a takaful fund based on joint assistance. The contribution is prepared through shared and reciprocal donation (tabarru') which does not constitute a profitable sale of coverage as happening in conventional insurance. Takaful involves individual charitable agreement (tabarru') contrary to the conventional insurance 
agreement that is a mutual agreement (mu'awadat). However, uncertainty (gharar) is accepted on an individual charitable agreement (Annuar, 2004). The idea of takaful is established on three basic philosophies; that is mutual responsibility, cooperation with each other and protecting one another from any type of troubles, tragedies and other calamities whereby the customer's contributions in the form of premium are founded on the notion of donation (tabarru') (Ayuba, 2014).

\section{Literature Review}

Takaful insurance emerged in Saudi Arabia more than thirty years ago. The Islamic Insurance Company (Takaful insurer) was established in Saudi Arabia in 1979. It was known as Weqaya Takaful Insurance and Reinsurance Company. And was regarded as the second established Takaful Company in the world after the first created Takaful Company in Sudan. From that year, the Takaful operations have grown in Saudi Arabia and regarded as the forefront among the Arab countries in Takaful development. On the other hand, major investment is needed to contest with the conventional insurance industry (Fisher and Taylor, 2000). However, Takaful industries in Saudi Arabia are less developed when equating with other Islamic countries like Malaysia and UAE. Many Takaful industries in Saudi Arabia have fruitfully grown at $10 \%$ or less per annum, while Dubai and Malaysia have grown at $60 \%$ or more per annum. In contrast to conventional insurance, most Saudi citizens are not buying insurance. May be because of the fact that, conventional insurance is against Islamic sharia. However, despite the long existence of Takaful products in Saudi Arabia, people are reluctant to buy and similarly, Takaful operators are in short supply (Hamid et al., 2011).

The Takaful companies have been supplying Islamic insurance products connecting to individual lines in restricted amounts. Therefore, on the mutual basis, Takaful operators are unable to indemnify massive commercial risks involving large amounts of capital because these risks will 
need insurance companies with massive amounts of capital. Consequently, the Saudi Arabian Monetary Agency (SAMA) has increased the share capital limit of Takaful company to one hundred million Saudi Riyals (SR100 million) and two hundred million Saudi Riyals (SR200 million) for re-Takaful companies in the Kingdom. Currently, there are six major Takaful industries in Saudi Arabia. They include Sabb Takaful, Al-Rajhi Takaful, Weqaya Takaful located in Riyadh and Al-Ahli Takaful, International Islamic Insurance Company and Islamic Arab Insurance Company located in Jeddah (Lim, 2010).

Takaful is derived from Arabic word which means solidarity and mutual assistance, whereby a group of participants agree among themselves to support one another, jointly against a defined loss. In a Takaful agreement, the participants contribute (consideration) a sum of money as wholly or partially tabarru (premium) into a common fund (pool), which will be used mutually to assist (compensate) any member who suffers a defined loss or damage (peril) (IFSB and IAIS, 2006).

Takaful from the Islamic perspective is a pooling system of community members who dwell on the principles of shared assistance and brotherhood in which participants donate money to support people who are in need, especially in times of financial problems. Practically, Takaful is a tool for alleviating any eventuality or danger on the life, property or business ventures of moslem and even non-moslems. It is regarded as a substitute for conventional insurance (Kadir, 2011).

It is suggested that the spirit of Takaful took place during the time of Prophet Muhammad (saw). Some verses of the holy Qur'an and hadith of the prophet talk about the concept of Takaful. Moslem are directed to collaborate with one another on the issue of righteousness and piety. The foundation of Takaful is stated in Qur'an, Al-Maidah [5]: 2 in which almighty Allah said, "... and cooperate (Ta'awun) in righteousness (Birr) and piety (Taqwa), but do not cooperate in sin and aggression. And fear Allah; indeed, Allah is severe in penalty." 
Similarly, the holy Qur'an talks about the concept of the moslem brotherhood, which is also another foundation of Takaful. Almighty Allah said in Qur'an, Hujurat [49]: 10: "The believers are but brothers, so make a settlement between your brothers. And fear Allah that you may receive mercy."

In the same direction, the concept of Takaful was also mentioned in the hadith of the prophet in the Sahih Al-Bukhari. vol. 8, no. 384. Prophet Muhammad (saw) said: "A moslem should be strong financially so that when he dies, his family will fulfil their needs from his wealth instead of leaving them in poverty to beg for alms from people"

The above Quranic verses and Hadith inspire the Moslem Ummah to create an Islamic financial system as an alternative to the conventional financial system. Islamic scholars recommend mudhärabah, mushäraka and wakala financial systems as an alternative model for investment drives. They also propose waqf as the best model for extenuation of risk and sharing of loss with each other's situation. The above takaful models are founded based on shared understanding and donation for the purpose of offering (tabarru') (Kasim, 2012).

There are several forms of contract that govern the relationship between the participants (policyholders) and the Takaful operator. The most widely used contracts are wakala (agency) contract, mudhärabah (profitsharing) contract and their hybrid (Noor and Abdullahi, 2016).

The sharia advisory council of Bank Negara Malaysia has made the resolution that Takaful contract is generally established on the sharia principles of tabarru' (donation) and ta'awun (mutual cooperation), apart from the agreement among the contracting parties. In the formulation of Takaful product, the principle of tabarru' has been the main underlying sharia principle, although the application of other principles such as wakalah and mudhärabah also complement the Takaful operational structure (Noor and Abdullahi, 2016).

The commonly used models by the Takaful operators are mudhärabah and wakala models. The mudhärabah is a profit sharing model of Takaful. The 
supervision and running of the Takaful fund, the product design and channel distribution of the product are all assigned to the Takaful operators. In this model, profits are shared among participants (rabbul maal) who are the providers of capital and the Takaful operators (mudhārib) who are the managers of the business. The profits obtained are shared according to the ratio agreed upon between the capital providers and the managers. But, losses in the business are credited to the participants. However, to safeguard the participants' interest, Takaful operators are required to strictly abide by the requirements and they should not invest the capital in unsafe and risky business (Mahmood, 2001). The above explanations on Takaful Model based on Mudhärabah Contract can be shown below in figure 1

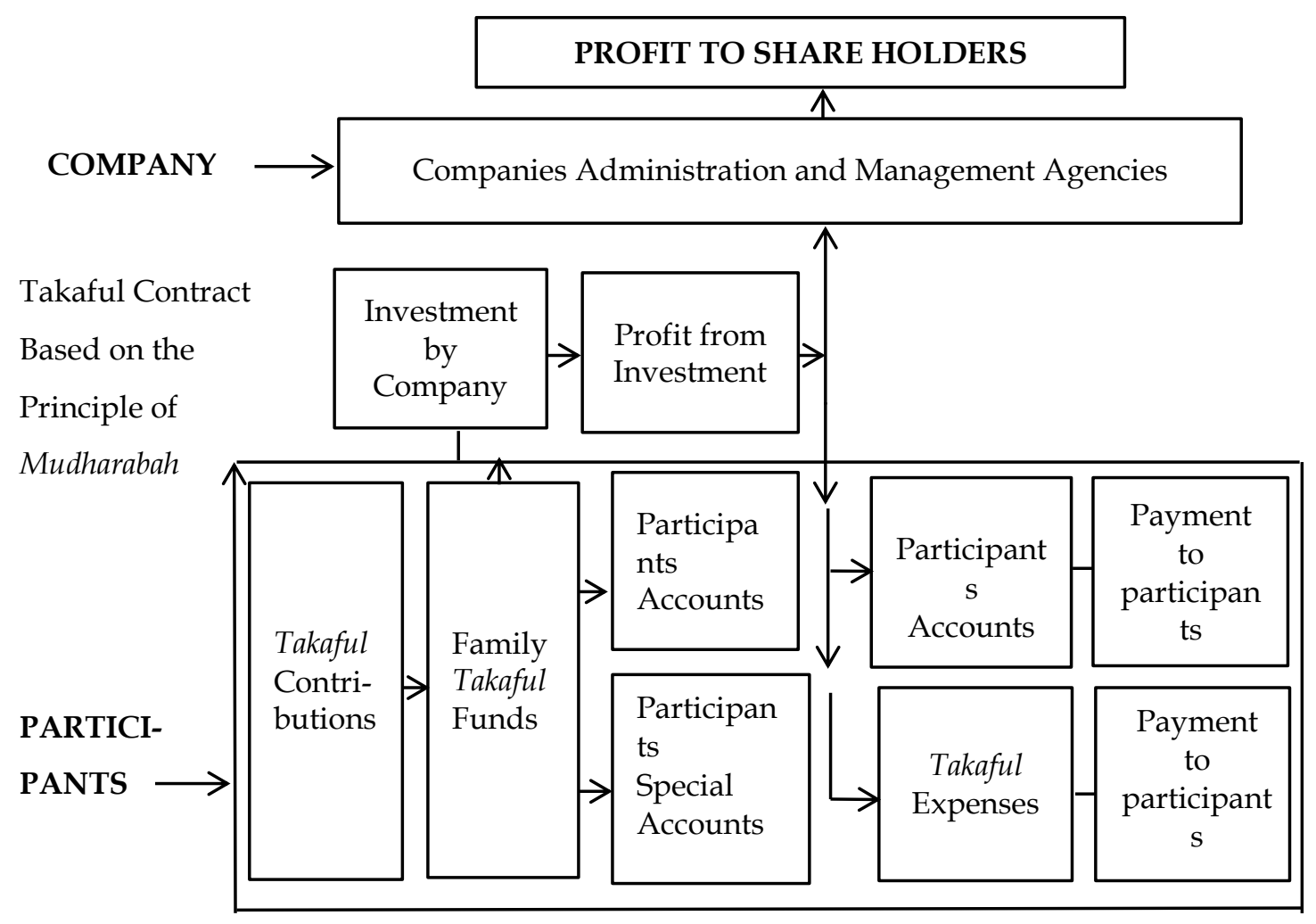

Figure 1. Showing Takaful Model Based on Mudhārabah Contract

Source: www.islamicbanker.com

The wakala model is an agency relationship between Takaful operators and participants. The participants are the capital providers who employ agents in the name of Takaful operators to take care of their business. 
Essentially, the Takaful operators serve as participants' agents and will be paid wakala fee for the services they provided. The fees are charged as a percentage of the investment profits earned, or based on the agreed ratio from the profits (Maiyaki and Ayuba, 2015).

The above explanations on Takaful Model based on Wakala Contract can be shown below in figure 2 .

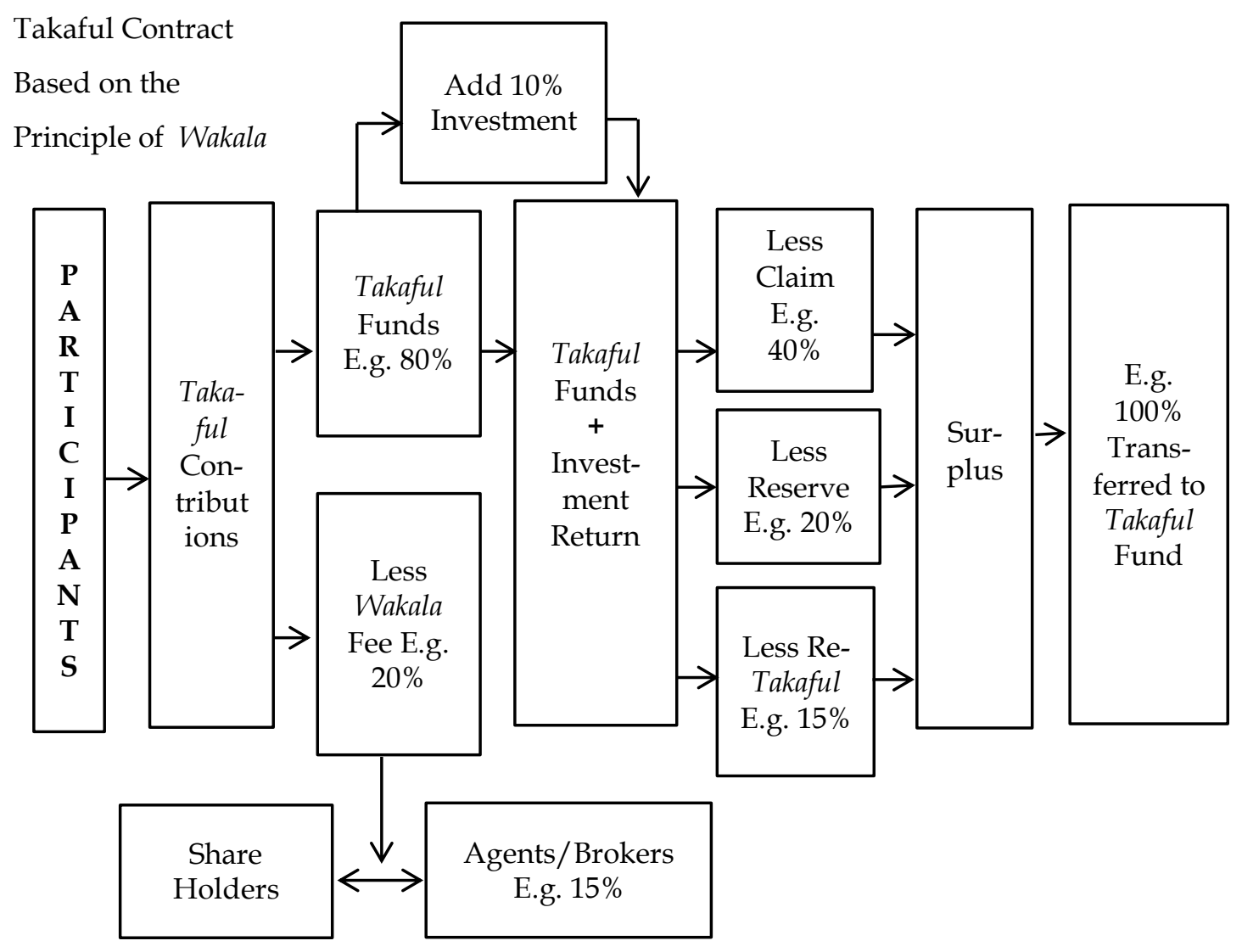

Figure 2. Showing Takaful Model based on Wakala Contract

Source: www.islamicbanker.com

Takaful is an alternative to conventional insurance. It is based on the principle of cooperation, mutual protection against losses of the members and social solidarity. It is a contract between people who decide to cooperatively share the liability for loss or damage that may impose on any one of them out of the fund they jointly contributed, however, in conventional arrangement loss is underwritten by the insurance company as stated by the terms and condition of the insurance policy (Maysami and William, 2011). Takaful is the 
model founded on the principle of shared collaboration and unity, as mentioned by Allah (SWT) in the Holy Qur'an, example in Surat Al-Maidah, verse 2 and Surat Ali Imran, verse 103 (Masud, 2011).

In contrast, the conventional insurance is a one-party risk reduction device popularly known as the insured, through the delivery of specific risks to another party, called the insurer, who propose a refurbishment, at least partly, of economic losses underwent by the insured (Naail and Norsham, 2014). Under the conventional insurance, there is no any religious limit. The key determination of insurance is for commercial purpose only in the form of protecting financial risk from the sorrow the complete cost of those activities on the natural surroundings which affect the insurer negatively (Zainuddin and Noh, 2013). The differences between Takaful and Conventional Insurance are summarised in table 1 below according to Yusuf et al. (2009):

Table 1. Showing Differences between Takaful and Conventional Insurance

\begin{tabular}{|c|c|c|}
\hline No. & TAKAFUL & CONVENTIONAL INSURANCE \\
\hline 1 & $\begin{array}{l}\text { Takaful is established based on sympathy; } \\
\text { therefore, any risk incurred is not } \\
\text { transferred, but pooled by the Takaful } \\
\text { participants. The Takaful operators } \\
\text { manage the Takaful industry. In operation, } \\
\text { they are equally the insurer and the } \\
\text { insured. }\end{array}$ & $\begin{array}{l}\text { In the conventional insurance, risk is } \\
\text { transferred from the insured (the } \\
\text { policyholder) to the insurer (the } \\
\text { insurance company). }\end{array}$ \\
\hline 2 & $\begin{array}{l}\text { The uncertainty level (gharar) is reduced to } \\
\text { a satisfactory level beneath Islamic sharia } \\
\text { by portraying the participant contributions } \\
\text { as donations (tabarru') and not a } \\
\text { commitment to alleviate the loss incurred } \\
\text { by any of the participants. }\end{array}$ & $\begin{array}{l}\text { The conventional insurance has an } \\
\text { element of uncertainty (gharar) which is } \\
\text { prohibited in Islam. There is an } \\
\text { uncertainty on the terms of the } \\
\text { contract, because it is not clear when } \\
\text { the loss will occur? And how much is } \\
\text { payable to each participant as } \\
\text { compensation for the loss suffered? }\end{array}$ \\
\hline
\end{tabular}


3 In Takaful, each participant pays The conventional insurance involves contribution in the spirit of brotherhood to gambling (maysir). The gambling is the take care of the losses of the group premium paid in anticipation of members. Profit and loss are mutually compensation. And if the expected loss shared by the participants. So, the Takaful does not occur, the policy holder loses operators are not affected by the loss in the amount paid as premium, but if any way. the loss occurs the insurance company lost a huge amount of money more than the premium collected from the insured. Therefore, gambling is prohibited in Islam.
4 In Takaful, the contributions collected from the participants are invested by the Takaful operators in non-interest based capitalization.

In conventional insurance, funds are invested by the insurance company at a fixed interest based capitalization. The interest generated is usury (riba) and is prohibited in Islam.

$5 \quad$ The accrued profit in Takaful industry is repaid to the participants according to the individual contributions.

In conventional insurance, the accrued profit goes to both the insured (policyholder) and the insurer (insurance company). Though the policyholder is protected throughout the period of the policy, but is not allowed to have any profit at the end of such period.

The following figure (figure 3) shows the differences between Takaful and Conventional Insurance. In Takaful, participants contribute money (tabarru') based on pooling system. The Takaful operators serve as the administrators and will be paid wakala fee for the services they provided. The fees are charged as a percentage of the investment profits earned or based on the agreed ratio from the profits. The money contributed is invested in non interest based ventures and the surplus is distributed as renewal. While for the Conventional Insurance, the policyholders would pay premium to the insurance company. The money collected by the insurance company as premium is invested in non-sharia compliant investment funds that will generate interest and the surplus are retained by the company. Therefore, in the Conventional Insurance, risk is transferred from the insured (the policyholder) to the insurer (the insurance company). 


\section{Takaful}

Risk are Shared between Participants

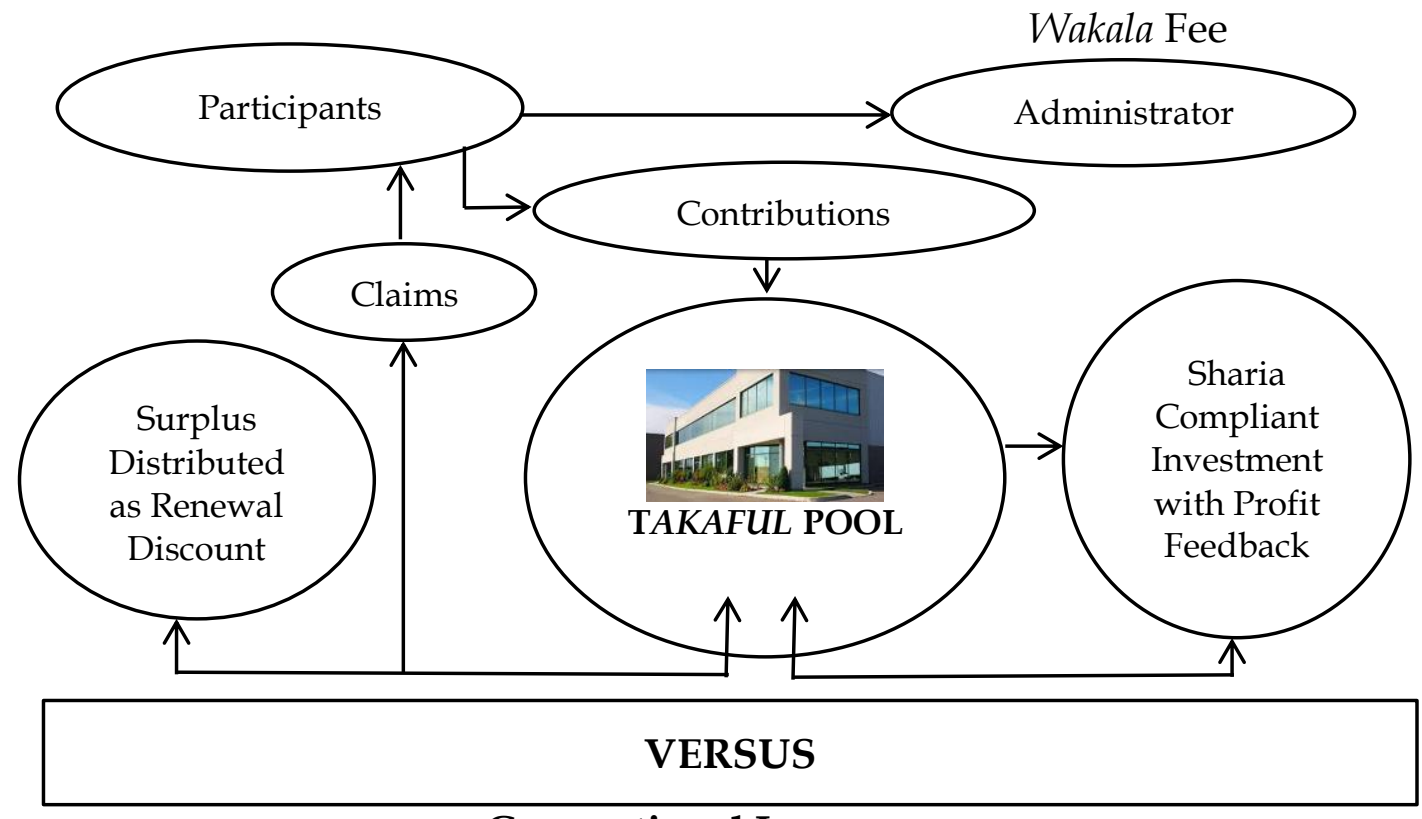

Conventional Insurance

Risk are Transferred to Insurance Company

(Resulting in Uncertainty and Gambling)

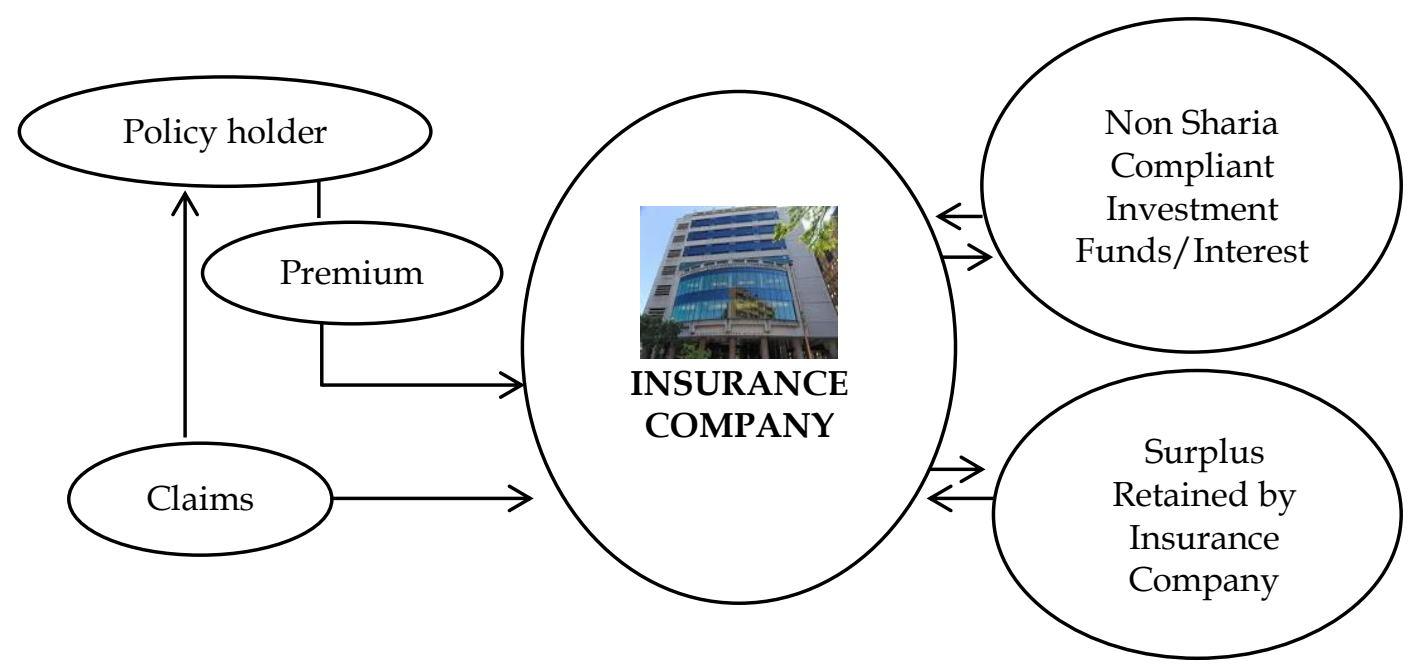

Figure 3. Showing The Differences between Takaful and Conventional Insurance

Source: Takaful Emarat (2016): www.takafulemarat.com 


\section{Method}

The paper utilized mixed method of data collection as a research design. Therefore the data was sourced through questionnaires which were administered to the Saudi Arabian citizens of their preference on the selection of Takaful over conventional insurance. Similarly, the research was supplemented by a face to face interview with customers drawn from the four selected Takaful industries in Saudi Arabia. They are Sabb Takaful, AlRajhi Takaful, Weqaya Takaful and Al-Ahli Takaful. This makes a total of four (4) respondents for the interview. The questionnaires included both closed and open ended questions. The close ended questions were expressed in either "yes or no" format while the open ended questions allowed the respondents to freely express themselves by writing down what they feel about the differences between Takaful and conventional insurance, as well as identify information about the Takaful products and services. The researchers employed the service of the research assistants to help the uneducated respondents to answer the questionnaires. Similarly, the interview administered, gave the researchers the opportunity to have face to face discussions with the respondents and also ask follow-up questions that are not contained in the interview protocol.

The questionnaires and interview protocol are the instruments used for data collection. The questionnaire was developed by the researchers and tagged Customer's Preference of Takaful Questionnaire (CPTQ). It was divided into two sections; the first section contains the demographic information of the respondents, while the second section contains questions that bother on the research topic. Equally, the interview protocol comprises of the demographic information of the respondents as well as the questions designed for the respondents on customer's preference on the selection of Takaful over the conventional insurance. Additionally, the interview conducted was semi-structured and was conducted with four respondents The 
researchers employ purposive sampling as a technique for selecting respondents for the interview in order to provide the desired information by knowing the minds, opinions, attitudes and feelings of the respondents. However, it is essential in a survey research to determine a sample size and deal with a non-response bias. Therefore, the common goal is to collect data representative of a population. The sample size for this research work is drawn from the ideal population, thus 150 samples were used for the study. Therefore, a total of one hundred and fifty respondents are distributed with questionnaires. The stratified random sampling technique was used for the administration of the questionnaires and all the questionnaires were returned by the respondents. The data collected from the respondents' questionnaires were analysed using simple percentage. While for the interview, the data collected were analysed using thematic analysis.

\section{Result and Analysis}

\section{Data Analysis}

The data collected from the questionnaires distributed to the respondents were analysed under the preference between Takaful and Conventional Insurance. This section explains customer's preferences between Takaful and Conventional Insurance in tabular form below.

Table 2. Do You Buy Any Insurance Product?

\begin{tabular}{lll}
\hline Purchase of Insurance Products & Frequency & Percentage (\%) \\
\hline Yes & 58 & 39 \\
No & 92 & 61 \\
\hline Total & 150 & 100 \\
\hline
\end{tabular}

Table 2 above indicates that out of the 150 respondents, $58(39 \%)$ of them agreed that they purchased insurance products, while 92 (61\%) respondents answered no to the question. They said, they did not buy an 
insurance product from any company. This shows that respondents who did not buy insurance product are the majority.

Table 3. What Insurance Product do You Subscribe to?

\begin{tabular}{llllllll}
\hline Type & Life & Health & $\begin{array}{l}\text { Building } \\
\text { and fire }\end{array}$ & Travel & Loan & Frequency & $\%$ \\
\hline Takaful & 5 & 14 & 12 & 7 & 5 & 43 & 29 \\
Conventional & 5 & 8 & 5 & 4 & 3 & 25 & 16 \\
$\begin{array}{l}\text { Insurance } \\
\text { Not Insured }\end{array}$ & 0 & 0 & 0 & 0 & 0 & 82 & 55 \\
\hline Total & & & & & & 150 & 100 \\
\hline
\end{tabular}

Table 3 above indicates that out of the 150 respondents, $43(29 \%)$ of them subscribe to Takaful products, while 25 (16\%) respondents subscribe to conventional insurance products. However, 82 (55\%) respondents are not insured to any insurance product. That is to say, they did not buy an insurance product from any company. This shows that respondents who are not insured are the majority.

Table 4. What is The Reason for Selecting Takaful or Insurance Company?

\begin{tabular}{lcc}
\hline Reasons for selection & Frequency & Percentage (\%) \\
\hline Religious Reason & 28 & 19 \\
Cost of the Insurance Policy & 14 & 9 \\
Easiness of recovering Damage & 18 & 12 \\
The nearest company to my place & 8 & 5 \\
None & 82 & 55 \\
\hline Total & 150 & 100 \\
\hline
\end{tabular}

Table 4 above indicates that out of the 150 respondents, 28 (19\%) of them believed that they selected Takaful or Insurance company because of the religious reason, while $14(9 \%)$ respondents selected Takaful or Insurance company due to cost of insurance policy. In addition to that, 18 (12\%) respondents selected Takaful or Insurance Company because of easiness of recovering damages. While 8 (5\%) respondents selected Takaful or Insurance 
Company due to the closeness of the company to their places. However, 82 (55\%) respondents have no reason to give, since they are not insured to any insurance product.

In addition to that, the results of the interview gathered from the respondents' information were presented and analysed. The views of the respondents were examined based on the following themes:

Themes of the Respondents' Opinions on the Differences between Takaful and Conventional Insurance

Various themes have been recognized based on the experience and interviews of the respondents. To allow proper understanding of the differences between Takaful and conventional insurance, all the themes generated were collected from the respondent's interview. A hard work was exerted to pinpoint the themes contained from the two terms "Takaful and conventional insurance" as well as the difference between them. The themes were grouped into two categories. Some respondents are of the view that the term Takaful is different from conventional insurance in the following way:

First, takaful contributions are based on the pooling system in accordance with sharia. This has categorically assisted the contributors to benefit with each other. Second, takaful is established on the basis of sympathy. Third, takaful is an Islamic insurance, which is conscious of the concept of sadaqah and tabarru'. Fourth, the goal of takaful is to enable all moslems avoid any form of gharar, maysir and riba.

However, a number of respondents believed that conventional insurance differs from Takaful due to the following:

First, the major differences between a conventional insurance and a Takaful is the transfer of risks. In conventional insurance risks are transferred from the insured to the insurer. Second, conventional insurance has an element of uncertainty that make it different from Takaful. Conventional 
insurance differs from Takaful on the issue of gambling in anticipation of compensation. Third, the conventional insurance generated interest from the amount of premium paid by the policyholders unlike the Takaful or Islamic insurance.

Themes of the Respondents' Motivational Factors that Influence their Preferences on the Selection of Takaful over Conventional Insurance

Themes generated from this section are obtained from the respondents' explanations on the motivational factors that influence their preferences on the selection of takaful over conventional insurance. The motivational factors include:

First, takaful is protected by sharia, especially the amount of share contributed as tabarru'. Second, takaful products and services have brighter future in Saudi Arabia due to the emergence of many Takaful industries and support from the government. Third, an absence of risks incurred or transferred. Fourth, funds contributed as donations are funded in the spirit of brotherhood. Fifth, the contributions made in the form of tabarru', are invested by the Takaful industry in non interest based capitalisation. Sixth, the profits obtained from the individual contributions of participants in Takaful are shared between the members according to their contributions. Seventh, the reduction or absence of uncertainty in Takaful influences respondent's preferences in the selection of Takaful over conventional insurance.

Themes of the Respondents' Views on the Importance of Takaful Products over Conventional Insurance

There are many importance of Takaful products over Conventional Insurance based on the interpretations of the respondents. Nevertheless, three 
themes emerged below which explained the importance of Takaful products over Conventional Insurance. These include:

First, takaful is more important than the conventional insurance, because it is part of obligation for moslems as sharia compliant. One of the respondents highlighted his views by narrating some verses of the Holy Qur'an as follows: "You will not attain righteousness till you spend in charity of the things you love" (Ali Imran [3]: 92).

Second, takaful is free from elements of interest (riba), uncertainty (gharar) and gambling (maysir).

Third, takaful is an act of worshipping Allah (SWT) which may attract reward. One of the respondents reported that many Qur'anic verses and traditions of the prophet Muhammad (SAW) motivate moslems to pay attention to their fellow moslems, which is the foundation of takaful and also encourage moslems to live with the spirit of obeying Allah's command and enjoy it as part of worship (ibadah).

Takaful assist members by helping each other willingly by contributing money as a pooling system. Promoting Takaful products and services by the takaful agents is an act of $d a^{\prime} w a h$.

\section{Discussions}

The findings of the study discussed in this section are categorized into two. The findings obtained from the questionnaires and the findings obtained from the interview. From the questionnaires, the findings of the study deliberated on the customer's preferences of Takaful over conventional insurance. On the issue of buying insurance products, the findings clearly indicate that the majority of people did not purchase insurance products from any insurance company; this is due to lack of awareness of the insurance benefits. This is similar to the findings of Izhar et al. (2010) which state that consumer mindfulness on Takaful products remain low, though this is 
regularly credited with inadequate understanding of Islamic finance in the banking and insurance world.

In terms of subscription to insurance product, the findings uncovered that majority of people did not subscribe to any insurance because of the stigma of conventional insurance as well as lack of knowledge about Takaful products and services. Therefore, the findings of the study correspond with the findings of Yusuf et al. (2009) which found out that people did not subscribe to any insurance because they embrace a negative approach toward insurance services.

However, on the reason for selecting Takaful or insurance company, the findings exposed that some people select Takaful products for religious purpose, while others select because of the cost of insurance products and others select because of the easiness of recovering damages. But, very few people select Takaful due to the nearness of Takaful Company to their places of residence. However, Yusof (2006) mentioned numerous reasons influencing the design and offerings of Takaful business. Firstly, moslems felt the need to practice Islam and apply its rules and regulations in full. Secondly, moslems wish a financial system that is capable to produce a rightly Islamic economy for the sake of the Moslem Ummah. Thirdly, with the formation of the Islamic banking system an inherent need arose for Takaful or Islamic insurance to supplement its services and contributions.

The findings of the study indicated that there are big differences between Takaful and conventional insurance. The concept of Takaful is different from conventional insurance because the donations are established at the pooling system in line with the sharia. This has certainly helped the donors to assist each other. This coincides with the findings of Maysami et al. (2011) which finds out that people donate on the bases of social solidarity, assistance and jointly sharing of losses of the members. It is a contract between a group of people who decide to equally share responsibility of 
damage or injury that may impose upon any of them; out of the fund they donate mutually but in conventional setup loss is insured. Also, Takaful or Islamic insurance varies from the conventional insurance, because it is founded on the basis of empathy and compassion. This study corroborated by the findings of Billah (2008) which stated that Islamic insurance differs from the conventional insurance in the following ways. Firstly, Islamic insurance has a dissimilar approach when setting a price policy on its products. For example, if one is not capable of meeting the premium payment thrice, the preceding money invested will be returned back to him after subtracting some related fees. This is not experienced in conventional insurance, in which case the money invested is regarded spent. Secondly, the practices as well as the theory of Islamic insurance are found in the Qur' an and the Hadith, at the same time conventional insurance has a restricted linkage to the spirit of any religion.

In the same direction, Takaful is mindful of the idea of tabarru' and sadaqah. Therefore, donating cash into the Takaful fund in the form of tabarru' is sadaqah and the reward from Allah is waiting for the donor or founder in the Hereafter. this is similar to the findings of Hamid et al. (2011) which confirm that Islamic insurance, which is popularly known as Takaful is based on the idea of tabarru' that is established on three principles: joint responsibility, collaboration with one another and defending one another from any kind of problems, tragedies and other adversities.

Similarly, Takaful allow all moslems to evade any form of gharar, maysir and riba that are all prohibited in Islam. This is similar to the findings of Abd-Rahman et al. (2008) which state that henceforth, Takaful products are intended to function as any other normal insurance products, but functioned in a different way to escape the forbidden elements and can be activated based on the notion of mudhärabah. Congruently, according to Amin (2012) Takaful is different from conventional insurance in the sense that the 
company is not the insurer protecting the participants. The persons taking part in the scheme jointly cover one another and this is the very essence of the word Takaful in Arabic. The conventional insurance is operated on risk assumption, but Takaful is based on shared co-operation. It means that, Takaful is a system of pooling funds to assist participants in future requirement.

Alternatively, the conventional insurance contrasts with the Takaful insurance because of the transfer of risks. That is to say, in conventional insurance risks are moved from the insured (the policyholder) to the insurer (the insurance company). This corresponds with the findings of Noor and Abdullah (2016) which found out that the risk in Takaful is not substituted by way of contribution payments given to the Takaful operator which means the Takaful operator is not selling and the contributor is not buying any risk coverage. In the same direction, Yusof (2006) believes that the operator is playing the role of fund managers in the best interests of the contributor. So the operator is not undertaking risk, the risk is though, circulated between the members who decided to mutually undertake the risk. Another study concerning risk was undertaken by Aris et al. (2012) which examined the risk of Takaful Company. It was resolved that as per alignment to the sharia requirements and the idea of Takaful, risk management practice and management of a Takaful operator were to be comfortable than a conventional insurance operator. Furthermore, defence in accordance to the Maqasid al-Shariah will have a tendency to be incorporated into the Islamic finance activities. Therefore, Takaful operators proposed to be active in handling their risks as part of good governance and best practice code.

The findings of the study indicated that the motivational factors that influence the preferences of takaful over conventional insurance are numerous. According to Gopy and Ramayah (2007), moslem customers that engaged with Takaful will have some valid factors on what convince them 
to select takaful. Those factors should be examined and provide a profound understanding of the motives behind the moslem customer preference of takaful over widespread conventional insurance. The findings of the study revealed that the factors that influence the preferences of Takaful over conventional insurance include protection of Takaful product by sharia. The person's compliance of sharia principles leads to their protection against any risk that is not transferable, but shared among contributors. This is similar to the findings of Chua (2010) which state that the features of sharia compliant insurance involve sincerity of both the parties and this policy is to their advantage, especially in the Hereafter and that it is legal in its objectives and operations. Therefore, takaful is a viable, profit-sharing, mudhārabah-based contract between the providers of funds who are the participants and the custodians and managers of the funds who are the takaful operators.

According to Engku (2008) prospects of takaful funds are bright, especially with the more competitive environment created by the emergence of many new takaful companies. She proposed and suggested on how to improve the prospects of takaful funds among others to create more regional or global investment-linked takaful funds with customercentric approach that offers many diversified and individually customized product features for better customers' attraction and satisfaction. Furthermore, the findings of the study exposed that the motivational factor that influence the preferences of takaful over conventional insurance is the anticipation of a brighter future of takaful products and services in Saudi Arabia. Likewise, lack of risk experienced or moved between contributors is another motivational factor that influences the preferences of takaful over conventional insurance. This relates to the findings of Billah (2001) which state that sharia compliant insurance is founded on mutual responsibility, shared collaboration and team spirit and also it is intended to defend the members against a clear risk. 
In the same direction, the motivational factor that influences the preferences on the selection of takaful over conventional insurance is that funds contributed as donations are funded in the spirit of brotherhood, that is to say customers preferred takaful products, because people contribute not with the intention of receiving any compensation or interest. This is similar to the findings of Billah (2001) which state that in takaful systems, contributors jointly decide to guarantee and to defend each other against a definite loss or harm, by mutually supplying financial support to any members in distress especially those who lose.

Also, the motivational factor that influences the preferences on the selection of takaful over conventional insurance is that the contributions made by the donors are invested by the takaful industry in non interest based capitalisation. Equally, the motivational factor that influences the preference on the selection of takaful over conventional insurance is that the profits acquired from the people's contributions in takaful are pooled between the members in consistent with their donations. Correspondingly, another motivational factor that influences the preferences on the selection of takaful over conventional insurance is the decrease or absence of uncertainty or gharar in takaful. Absence of uncertainty encouraged customers to subscribe to takaful products and services.

The findings of the study highlighted that the importance of takaful product over conventional insurance includes part of obligation for moslems as sharia compliant. That is to say takaful products are more important than the conventional insurance, because the former is part of the duty of every moslem. This is similar to the findings of Naail and Norsham (2014) which state that takaful is more widely held among the Saudi Arabian population at large, as compared to conventional insurance, because of its sharia compliant characteristics comprising the general opinion that conventional insurance is un-Islamic. Similarly, the findings of the study discovered that 
takaful is free from the elements of interest (riba), uncertainty (gharar) and gambling (maysir). This corresponds with the findings of MdRazak et al. (2013) which found out that the Takaful business is aimed at protecting the members against a defined risk. It is an arrangement that is free from the three elements of uncertainty (gharar) reg arding premium and coverage, gambling (maiysir) and interest (riba) which are the three basic ideologies of Islamic Finance.

Correspondingly, the findings observe that the importance of takaful product over conventional insurance is that takaful is an act of worshipping Allah (SWT) which may attract reward. That is to say people subscribe to takaful products and services because contributing tabarru' in takaful is an act of ibadah. Furthermore, the findings of the study uncovered that subscribing to takaful products enable contributors to assist each other freely by donating money as a pooling system. Therefore, the findings of the study correspond with the findings of Syarikat Takaful Insurance Company (2009) which found out that both the participants and takaful operators are jointly assisting one another for a financial protection. Such a shared co-operation among both parties is indeed in line with the Qur'anic principle of joint collaboration. In addition to that, the findings exposed that as part of the importance of takaful product over conventional insurance, promoting takaful products and services by the Takaful agents is an act of $d a^{\prime} w a h$ and their reward is awaiting them in the hereafter.

\section{Conclusion}

The research identifies the factors that influence customer's preferences on the selection of takaful over conventional insurance among the people of Saudi Arabia. The shortage of education and awareness about the takaful products and services based on sharia among the people necessitates the need to conduct a survey research as well as the empirical study on the issue. takaful is a concept that has been in existence for centuries. takaful business 
permits policyholders to cherish the benefits of a joint structure in a shareholder package. The takaful business also has a clear moral structure which can be advertised to both moslems and even non-moslems. Whereas, both takaful and conventional businesses offer proceeds for the shareholders. However, in takaful business the expenditures paid to the shareholders are openly obvious, while in conventional insurance they are not certainly clear.

Based on the findings of the study, there are some differences between takaful and conventional insurance such as contribution placed in the pooling system which definitely helped the contributors to benefit with each other. Also takaful is established on the basis of sympathy where the contributors, co-operatively shares the liability for any loss or damage that may befall on any member. Also, people are aware of the idea of sadaqah and tabarru' of which the reward is awaiting the contributor in the hereafter. Likewise, takaful enable all moslems to escape gharar, maysir and riba which are prohibited in Islam. While the conventional insurance differs from takaful in the sense that it is based on transfer of risks from the insured to the insurer, Also in conventional insurance there is an element of uncertainty (gharar), gambling (maysir) in the form of premium and interest rate generated from capitalization is usury (riba).

In addition to that, the findings uncover the protection of takaful product by sharia especially the amount of share contributed. And the brighter future of takaful in Saudi Arabia due to the emergence of many Takaful industries and support from the government. Similarly, another motivational factors that influence customer's preferences is the absence of risk incurred or transferred to participants. Likewise, funds are contributed in the spirit of brotherhood for all members since they care for each other's problems and happiness. Moreover, another motivational factor is that contributions (tabarru') are invested in non-interest based capitalization by the takaful agents and profits are shared according to individual contributions. In 
the same direction, customers are motivated by the reduction of uncertainty (gharar) level in takaful.

Finally, the findings revealed that the importance of takaful products over conventional insurance includes considering takaful as part of obligation for moslems as a sharia compliant. Also takaful is free from elements of riba, gharar and maysir which are all prohibited in Islam. Another importance of takaful products over conventional insurance is that the former is regarded by all moslems as an act of worship which may attract a reward from Allah, the almighty as well as helping one another through a pooling system of contributions. Then, promoting takaful products by the takaful agents is an act of da'wah.

The recommendation put forward by the researcher include as follows:

The takaful operators should prepare additional promotion or advertisement, as a small number of people have an idea about the takaful products and services for example through exhibition and road exhibition for public awareness.

Takaful operators should develop their customer care services in such a way that phone calls, letters and text messaging made by the customers for future payments are provided.

It is essential to carry out a regular study on consumer perceptions about their takaful products and services. This can assist in providing feedback from their consumers who can then be used to develop their products and services.

Takaful companies should create additional consciousness of Saudi Arabian citizens about the differences between takaful and conventional insurance since the greatest number of respondents has no idea about it. They should lay emphasis on the benefits of takaful in comparison with the conventional insurance. 
Takaful companies should provide further remarkable offers or packages on their insurance, which can be completed either four times or two times a year, so as to draw more consumers in their advertising.

Takaful companies could provide motivational speech to higher institutions of learning on the student's acceptance of takaful products and service which they can subscribe after graduation.

There should be cooperation between the Islamic Bank Insurance and the Ministry of Higher Education to take in some basic information about yakaful as part of the curriculum for higher education in Saudi Arabia being an Islamic country. Simultaneously, the educationalists in the kingdom should facilitate them on the Islamic system of insurance.

The takaful operators should enlighten the current and potential subscribers relating to the benefits of Islamic insurance products. It is an indispensable way of teaching constructive attitude towards the takaful products. This involves assigning experienced and well-informed agents or personnel as an effective way of managing takaful products and service.

The role of people in the framework of personal norm is absolutely essential. Therefore, the existing consumers should be treated ethically and professionally in such a way that some them should be appointed as "agents" for the takaful operators which serve as the positive methods of attracting more consumers to take part in Islamic insurance.

The takaful operators should amend their operations which are perceived as professional and transparent capable of solving the problems of the customers on risk management products. The takaful operators should also work hard in distinguishing themselves from the conventional insurance operators who would build new reputation, in addition to conquering people belief and self-assurance.

Takaful companies need to promote the importance of takaful products vigorously together with the Saudi Arabian government 
inventiveness in imparting Islamic values amongst moslem consumers, particularly the youths.

\section{References}

Abdul-Hamid, M., Osman, J. and Amin-Nordin, B.A. (2009). Determinants of Corporate Demand for Islamic Insurance in Malaysia. International Journal of Economics and Management, Vol. 3 (2): 278-296.

Ab-rahman, A., Ali, N., Che-Seman, A. and Wan-Ahmad, W.M. (2008). Comparative Study between Auto Takaful and Auto Insurance Purchasing Behaviour among Malaysian Undergraduates. Jurnal Syariah, Vol. 16 (1): 75-88.

Amin, H. (2012). An Analysis on Islamic Insurance Participation. Jurnal Pengurusan, Vol. 34: 11 - 20.

Annuar, H. A. (2004). Al-Wakalah and Customers' Preferences toward It: A Case Study of Two Takaful Companies in Malaysia. The American Journal of Islamic Social Sciences: 28-49.

Aris, N. A., Tapsir, R., and Talib, M. K. A. (2012). Risk and Risk Management of Takaful Industry. Journal of Global Business and Economics, Vol. 4 (1).

Ayuba, F. (2014). Non-economic Factors Influencing the Islamic Insurance (Takaful) Services Consumption in Kano Metropolis, Nigeria; unpublished M.SC. Dissertation submitted to the Department Business Administration and Entrepreneurship Studies, Bayero.

Billah, M.M. (2008). Islamic Insurance: Its Origins and Development. Arab Law Quarterly, Vol. 13 (4): 386-422.

Billah, M. M. (2001). Principle of Contract Affecting Takaful and Insurance Compared. Part 1: Arab Law Quarterly (London).

Chua Abdullah, O. (2000). A Critical Evaluation of Insurance and Takaful. Proceedings from the International Conference on Takaful/Islamic Insurance, Kuala Lumpur.

Engku, R. A., Engku, A. and Hassan, Scott P. O. (2008). Essential Guide to Takaful. Kuala Lumpur, CERT :157-158

Fisher, O. C., Taylor, D. (2000). Prospects for the Evolution of Takaful in the 21st Century. Proceedings of the Fifth Harvard University Forum on Islamic Finance: Islamic Finance: Dynamics and Development Cambridge: 237254.

Hamid, M. A., and Rahman, N. M. N. A. (2011). Commitment and Performance: A Case of Takaful (Islamic Insurance) Representatives in 
Malaysia. Australian Journal of Basic and Applied Sciences, Vol. 5 (10): 777785 .

Islamic Financial Services Board (IFSB) and International Association of Insurance Supervisors (IAIS). 2006. Issues in Regulation and Supervision of Takaful.

Jacky Lim, M. F. (2010). History, Progress and Future Challenge of Islamic Insurance (Takaful).

Kadir, M. R. A. (2011). Our Strategy Towards Developing a Progressive Takaful Industry. Keynote Speaker at the Official Launch of AIA AFG Takaful Berhard, Kuala Lumpur, 28 January 2011. Retrieved from: http:/ / www.bnm.gov.my/index.php?ch=9andpg=15andac=395,

Kasim, N. A. A. (2012). Disclosure of Shariah Compliance by Malaysian Takaful companies. Journal of Islamic Accounting and Business Research, Vol. 3 (1): 20-38.

Mahmood, N.R. (2001). Takaful: The Islamic System of Mutual Insurance: The Malaysian Experience. Arab Law Quarterly, Vol. 6 (3): 280-296.

Maiyaki, A.A. and Ayuba, H. (2015). Consumers' Attitude toward Islamic Insurance Services (Takaful) Patronage in Kano Metropolis, Nigeria. International Journal of Marketing Studies, Vol. 7 (2).

Masud, H. (2011). Takaful: An Innovative Approach to Insurance and Islamic Finance. U. PA. J. Int.1., Vol. 32 (4): 1131-1164.

Maysami, R.C., and Williams, J.J. (2011). Evidence on The Relationship between Takaful Insurance and Fundamental Perception of Islamic Principles. Applied Financial Economics Letter, Vol. 2 (4): 229-232.

MdRazak, M. L., et al. (2013). Acceptance Determinants toward Takaful Products in Malaysia. International Journal of Humanities and Social Science, Vol. 3 (17).

Mohd. Izhar, Tariq Masood and Mohd Saeed Khan (2010). Problems and Prospects of Islamic Banking: A Case Study of Takaful. Aligarh Muslim University, Aligarh, India.

Naail, M.K. and Norsham, M.N. (2014). Factors Influencing the Choice of Takaful Over Conventional Insurance: The Case of Malaysia. Journal of Islamic Finance, Vol. 3 (2): 001 - 014. IIUM Institute of Islamic Banking and Finance.

Noor, A. M., and Abdullah, M. A. (2009). Takaful (Islamic Insurance) Benefit: Ownership and Distribution Issues in Malaysia. Journal of Islamic Economics, Banking and Finance. 
Syarikat Takaful Insurance Company. (2009). Al-Mudharabah. Retrieved from http: www.takaful- malaysia.com/mudh/mudh.htm, 28 March 2012.

Yusof, M. F., (2006). Takaful (Islamic Insurance) Concept and Operational System from the Practitioner's Perspective. Kuala Lumpur: BIMB Institute of Research and Training. Page: 7-15.

Yusuf, T. O., Gbadamosi, A., and Hamadu, D. (2009). Attitudes of Nigerians toward Insurance Services: An Empirical Study. African Journal of Accounting, Economics, Finance and Banking Research, Vol. 4(4): 34-46.

Zainuddin, S., and Noh, I. N. M. (2013). An Overview of The Emergence of Takaful: An Islamic Type of Insurance Policy. International Journal of Business and Economics Research, Vol. 2 (5): 112-115. 